University of Chicago Law School

Chicago Unbound

Journal Articles

Faculty Scholarship

1978

\title{
Human Cannonballs and the First Amendment: Zacchini v. Scripps-Howard Broadcasting Co.
}

Douglas G. Baird

Follow this and additional works at: https://chicagounbound.uchicago.edu/journal_articles

Part of the Law Commons

\section{Recommended Citation}

Douglas G. Baird, Note, "Human Cannonballs and the First Amendment: Zacchini v. Scripps-Howard Broadcasting Co.", 30 Stanford Law Review 1185 (1978).

This Article is brought to you for free and open access by the Faculty Scholarship at Chicago Unbound. It has been accepted for inclusion in Journal Articles by an authorized administrator of Chicago Unbound. For more information, please contact unbound@law.uchicago.edu. 


\section{NOTES}

\section{Human Cannonballs and the First}

\section{Amendment: Zacchini v. Scripps-Howard Broadcasting Co.}

In 1973, Hugo Zacchini, a human cannonball, sued the ScrippsHoward Broadcasting Co. for unlawfully appropriating his professional property. ${ }^{1}$ Scripps-Howard ${ }^{2}$ had filmed Zacchini's performance at an Ohio county fair and shown 15 seconds of its film on its 11 o'clock evening news program. ${ }^{3}$ In its defense, Scripps-Howard claimed a first amendment privilege to broadcast the film. ${ }^{4}$ (1977).

1. See Appendix at 4, Zacchini v. Scripps-Howard Broadcasting Co., 433 U.S. 562

2. This Note uses "Scripps-Howard" to refer collectively to the named defendant, Scripps-Howard Broadcasting Co., its television station, WEWS, and WEWS employees.

3. 433 U.S. at 564.

4. The first amendment issue arose during the course of appeals from the state trial court's entry of summary judgment for Scripps-Howard. An Ohio state court of appeals reversed the trial court, holding sua sponte that Zacchini had stated two causes of action: conversion of property and infringement of common law copyright. See id. at 564 . The unreported opinion of the court of appeals is reprinted in Petition for a Writ of Certiorari, Appendix at 27, Zacchini v. Scripps-Howard Broadcasting Co., 433 U.S. 562 (1977).

Scripps-Howard appealed to the Ohio Supreme Court, asserting that neither cause of action was appropriate. In reversing, the Ohio Supreme Court agreed with Scripps-Howard, finding the intermediate state court's extension of the conversion doctrine to be "confusing, unnecessary, and improper." Zacchini v. Scripps-Howard Broadcasting Co., 47 Ohio St. 2d 224, 227, 351 N.E.2d 454, 457 (1976). Further, the Ohio Supreme Court doubted that copyright protection extended to human cannonballs, and declared that Zacchini, in performing numerous times before live audiences, had "published" the act and thereby terminated whatever common law copyright protection he might have had. Id. at 227-28, 351 N.E.2d at 457 .

The Ohio Supreme Court did acknowledge that Zacchini might have an action against ordinary infringers for invasion of his right to privacy on the basis of an appropriation of his "likeness and identity." Id. at 228-31, 351 N.E.2d at 458-59. But the court held that the first amendment privileged the press to make such an appropriation: "The press, if it is to be able to freely report matters of public interest, must be accorded broad latitude in its choice of how much it presents of each story or incident, and of the emphasis to be given such presentation. No fixed standard which would bar the press from reporting or depicting either an entire occurrence or an entire discrete part of a public performance can be formulated which 
In Zacchini v. Scripps-Howard Broadcasting Co. ${ }^{5}$ the United States Supreme Court examined the limits the first amendment places on the right of entertainers to control public dissemination of their performances. In a 5-4 decision, the Court ruled for Zacchini, declaring that the first amendment did not give Scripps-Howard the right to appropriate Zacchini's "entire act." Writing for the Court, Justice White asserted that state-created rights of performance ${ }^{7}$ are a valid

would not unduly restrict the 'breathing room' in reporting which freedom of the press requires." Id. at 235,351 N.E.2d at 461.

Zacchini petitioned the United States Supreme Court for a writ of certiorari on the ground that the Ohio Supreme Court had improperly interpreted the first amendment. Essentially, Zacchini argued that the Ohio Supreme Court had confused the standard for one type of invasion of privacy, the "false-light privacy" action, see Prosser, Privacy, 48 CaLrf. L. REV. 383, 398-401 (1960), with the standard for another type of invasion of privacy, misappropriation of name and likeness, see id. at 401-07. Petition for a Writ of Certiorari at 8-11, Zacchini v. Scripps-Howard Broadcasting Co., 433 U.S. 562 (1977). The United States Supreme Court granted certiorari. 429 U.S. 1037 (1977). In its brief, Scripps-Howard argued primarily that the decision of the Ohio Supreme Court should stand because it rested on adequate and independent state grounds, Brief for Respondent at 9-20, Zacchini v. ScrippsHoward Broadcasting Co., 433 U.S. 562 (1977), but Scripps-Howard also urged that the Constitution mandated a press privilege regardless of state law, $i d$. at 21-23.

5. 433 U.S. 562 (1977).

6. Id. at 576-77. In delivering the opinion of the Court, Justice White reversed the Ohio Supreme Court on the grounds that the latter had erroneously interpreted the first amendment. See id. at 570-75. For the Ohio Supreme Court's interpretation, see note 4 supra. The state of Ohio, of course, remains free to privilege the press as a matter of state law beyond federal requirements. 433 U.S. at 578-79. On remand, the Ohio Supreme Court held that the press had no state constitutional privilege to show the act and remanded the case for trial to determine if Scripps-Howard infringed Zacchini's common law rights. 54 Ohio St. 2d 286, 376 N.E.2d 582 (1978). The case presently awaits trial.

There were two dissenting opinions in Zacchini. In strongly rejecting the "entire act" test, Justice Powell, joined by Justices Brennan and Marshall, declared that the press should be privileged in filming a public performance so long as it does not do so as "a subterfuge or cover for private or commercial exploitation." 433 U.S. at 581 (Powell, J., dissenting). Justice Stevens also dissented, expressing uncertainty whether the state court's action had rested on state as well as federal grounds, and advocating a remand for clarification. Id. at 583 (Stevens, J., dissenting).

7. See 433 U.S. at 576 . This Note refers to the type of right asserted by Zacchini as a "right of performance." Justice White's majority opinion, Justice Powell's dissent and the Ohio Supreme Court opinion instead refer to Zacchini's interest as a "right of publicity." See 433 U.S. at 569-74. But a "right of publicity" is clearly distinct from the interest Zacchini claimed. Generally, rights of publicity are the rights of entertainers and athletes to control the commercial exploitation of their personal images-their names and likenesses. See Haelan Laboratories v. Topps Chewing Gum, Inc., 202 F.2d 866, 868 (2d Cir. 1953). Zacchini claimed that Scripps-Howard had appropriated his actual performance, rather than his public image as made marketable by the success of that performance; the distinct purpose underlying Zacchini's claimed interest is ensuring that performers retain an economic incentive to create new performances. 433 U.S. at 576 . But the occasionally subtle line between rights of performance and rights of publicity requires closer scrutiny.

Commentators have found two principal justifications for rights of publicity. First, these rights may protect the privacy interests of celebrities who arguably have the same right as ordinary people to prevent others from exploiting their personal identities in public with- 
and desirable means of providing entertainers with an economic incentive to continue performing. While he recognized that entertainment could be legitimate news to which the public has a first

out permission. See Bloustein, Privacy as an Aspect of Human Dignity: An Answer to Dean Prosser, 39 N.Y.U. L. REv. 962, 989 (1964). Second, rights of publicity function like trademarks: They promote the flow of useful information about commercial goods and services to the public by ensuring that the public is not confused by a false implication that a particular celebrity has endorsed a particular good. See Treece, Commercial Exploitation of Names, Likenesses, and Personal Hislories, 51 TEx. L. REv. 637, 644-48,671-72 (1973). This justification is rooted in the law of unfair competition. See Nimmer, The Right of Publicity, 19 LAw \& CONTEMP. PROB. 203, 210-18 (1954).

The privacy justification for rights of publicity is fairly weak. Warren and Brandeis, who virtually created the right to privacy, asserted that people lose rights to privacy in things which they make public, and thereby clearly implied that performers could have no privacy interest in their names and likenesses. Warren \& Brandeis, The Right to Privagy, 4 Harv. L. REv. 193, 215 (1890); see Man v. Warner Bros., 317 F. Supp. 50 (S.D.N.Y. 1970) (musician recorded in public performance in movie Woodstock made himself newsworthy and therefore had no privacy claim); $f$. Gertz v. Robert Welch, Inc., 418 U.S. 323, 342, 345 (1974) (dictum) (because of first amendment, individuals who become public figures by thrusting themselves into matters of public interest cannot sue for injury to reputation unless they can prove reckless disregard of truth).

The unfair competition basis for rights of publicity is much stronger, however, and differs only subtly from the policy underlying rights of performance. Rights of publicity help consumers make rational economic choices by preventing consumer confusion over whether the person whose name or likeness is associated with the product actually endorses it. Rights of performance, on the other hand, protect not information about a good, but rather a good which is itself information-the performance., Rights of performance therefore are not designed to prevent deception as are rights of publicity. Consumers derive the same value from the cannonball act whether they pay Zacchini or watch the act for free on television. Denying the public access to the act without the performer's permission serves the public interest in acquiring information only to the extent that it helps the performer secure compensation necessary to induce the performance. The balance to be struck between promoting clear and nondeceptive information about commercial goods and services and allowing uninhibited speech about such goods and services (as when one manufacturer wants to use the name or likeness associated with a competitor's product to facilitate a comparison with its own goods) is different from the balance to be struck in the case of rights of performance, when the speech at issue is itself the good that is being sold. The concern in the second instance is not what information the public receives, but rather that it receives as much as is consistent with the economic incentives the performer needs. In the case of rights of performance, what is erroneous and malformed will be exposed in the marketplace of ideas, provided economic incentives place the information in the market to begin with. By contrast, in rights of publicity cases, the right to control name and likeness exists not in the first instance to recognize the investment necessary to acquire a reputation, but rather to ensure that the market for ordinary goods and services is not disrupted by confusing information that undermines the ability of the consumer to make rational economic choices.

Of course, some claims will combine rights of performance with rights of publicity. Such cases require a balancing of the first amendment interest against both the need to ensure that commercial information flows cleanly as well as freely, see Virginia State Bd. of Pharmacy v. Virginia Citizens Consumer Council, Inc., 425 U.S. 748, 771-72 (1976), and the need to provide performers with economic incentives. But Zacchini is not one of these cases; nothing in the record suggested that Zacchini had tried to market his name or likeness or could have if he had wanted to. 
amendment right of access, Justice White insisted that state rights of performance do not prevent the press from reporting to the public the newsworthy information to which it is entitled. ${ }^{8}$

Zacchini's interest in controlling dissemination of his performance is a proprietary interest similar to a copyright. When a state grants legal recognition to such an interest, it is striking a balance between public access to performances and economic incentive for entertainers to continue performing. Creating this balance is not the job of the Court. ${ }^{9}$ But the Court does have the responsibility of monitoring state creation of such a balance to prevent infringement of the first amendment. ${ }^{10}$ This Note argues that the Zacchini Court, though it generally appreciated the interests competing in the balance, did not accurately perceive its role in the conflict between

8. 433 U.S. at 574.

9. On the federal level, the power to create intellectual properties is the responsibility of Congress. The Constitution gives Congress the power to "promote the Progress of Science and useful Arts, by securing for limited Times to Authors and Inventors the exclusive Right to their respective Writings and Discoveries." U.S. CoNST. art. I, § 8, cl. 8. Zacchini, 433 U.S. at 577, and other recent cases, Kewanee Oil Co. v. Bicron Corp., 416 U.S. 470, 478-79 (1974); Goldstein v. Galifornia, 412 U.S. 546, 552-60 (1973), recognized that states had the right through the powers reserved to them through the ninth and tenth amendments to create intellectual properties in areas that Congress had not preempted.

10. Whatever else may be necessary or appropriate in allocating rights between press and performer, the first amendment demands that the allocation of rights does not inhibit wide-open debate. In other first amendment areas, the Court has seen itself as bound to ensure that criticism of public figures and discussion of public issues is not stifled. See, e.g., Time, Inc. v. Hill, 385 U.S. 374 (1967) (right to maintain false-light privacy action under state law must fall to first amendment interest in allowing press to print matters of public interest); New York Times Co. v. Sullivan, 376 U.S. 254, 283 (1964) (first amendment delimits state's power to award damages for libel in actions brought by public officials against critics of their conduct); of. Brandenburg v. Ohio, 395 U.S. 444 (1969) (guarantees of free speech forbid state to proscribe advocacy of the use of force or violation of law unless it incites imminent lawless action and is likely to produce such action). The Court should feel no less constrained when confronting the same first amendment concern in cases involving rights of performance. Rights of performance are illegitimate to the extent that they prevent the open debate that the Constitution mandates.

The constraints of the first amendment are no less applicable merely because the countervailing interest is a state-created propetty interest. Ordinary property interests, such as those in real property, have long coexisted with first amendment rights, and courts have seldom confronted a conflict between them. In the last decade, however, the Supreme Court has addressed a real property-first amendment conflict in cases involving the power of owners of real property open to the public, such as a shopping center, to constrain speech. See, e.g., Hudgens v. NLRB, 424 U.S. 507 (1976); Lloyd Corp. v. Tanner, 407 U.S. 551 (1972); Food Employees Local 590 v. Logan Valley Plaza, Inc., 391 U.S. 308 (1968). Although the shopping center cases appear to conclude that the value of preserving real property interests generally outweighs the restraint such interests impose on freedom of expression, the Court did advert to the constraints such rights place on the first amendment: "It would be an unwarranted infringement of property rights to require them to yield to the exercise of First Amendment rights under circumstances where adequate altemative avenues of communication exist." Lloyd Corp. v. Tanner, 407 U.S. 551, 567 (1972) (dictum) (emphasis added). 
rights of performance and the first amendment: to ensure that the rights of performance do not stifle "uninhibited, robust, and wideopen" " debate on any matter of public concern. Though the states are free to create intellectual properties, they cannot strip the press of the capacity to evaluate and criticize public performances.

The Court's ultimate holding in Zacchini is sufficiently narrow that it does not strictly foreclose state courts from finding in their own law the proper accommodation of public access and performer incentive. But in its reliance on the "entire act" standard, ${ }^{12}$ the Court did not give lower courts much-needed guidance in ensuring that future accommodation respects the first amendment.

Part I of the Note demonstrates the nature of Zacchini's interest as an analogue to a copyright, and identifies the Court's proper role in overseeing the creation of such a property interest. Part II examines the premises of the Zacchini opinion and explains why the formulas for accommodation offered by both the majority and the dissent inadequately identify the public's interest in critical scrutiny of public performances. Part III identifies the factors that should comprise a model of accommodation by drawing an analogy to fair use doctrine in copyright, and concludes that Zacchini, though not itself providing such a model, leaves the states a rich opportunity to develop one through their common law.

\section{The Purpose of Rights of Performance and the COURT'S ROLE IN THEIR GREATION}

Zacchini essentially claimed that Scripps-Howard had unlawfully appropriated his performance as a human cannonball and disseminated it to its own profit. He argued that, as a product of his talent and energy, the cannonball act was a marketable good, and that as its creator he was fully entitled to its market value. ${ }^{13}$ The broad doctrine that International News Service v. Associated Press ${ }^{14}$ and its progeny ${ }^{15}$ established-that one has a right to reap what one has

11. New York Times Co. v. Sullivan, 376 U.S. 254, 270 (1964).

12. See 433 U.S. at $575-76$.

13. Brief for Petitioner at 30 , Zacchini v. Scripps-Howard Broadcasting Co., 433 U.S. 562 (1977).

14. 248 U.S. 215 (1918). The INS case was decided under general federal common law, which was abolished in Erie R.R. v. Tompkins, 304 U.S. 64 (1938); the case therefore did not offer precedent for the Court in Zacchini.

15. See, e.g., Ettore v. Philco Television Broadcasting Corp., 229 F.2d 481 (3d Cir.), cert. denied, 351 U.S. 926 (1956) (boxer has action for misappropriation for unauthorized telecast of fight film); Pittsburgh Athletic Co. v. KQV Broadcasting Co., 24 F. Supp. 490 (W.D. Pa. 
sown-appears to support Zacchini's claim. But analogy to federal copyright law ultimately provides a sounder foundation for understanding Zacchini's interest, and helps define the proper role of the Court in overseeing the legal recognition of that interest.

\section{A. Scripps-Howard's Broadcast as Misappropriation and Unjust Enrichment}

The Gourt began its analysis of Zacchini's claim by placing it principally in the context of cases granting performers the right to sue for misappropriation of their performances. ${ }^{16}$ Freedom to film the cannonball act without compensating Zacchini allows ScrippsHoward to benefit from the act at no cost beyond its own production expenses. A right to control the dissemination of their performances enables entertainers to secure compensation for the benefit their performances bestow on others, and therefore finds an apparent basis in equitable principles of unjust enrichment. ${ }^{17}$

But though it may seem highly inequitable for one party to obtain at no cost something of market value to another, the unjust enrichment rationale for Zacchini's claim has two limitations. First, the "market" value of a performance derives in large part from a

1938) (radio station has no right to broadcast without permission play-by-play of professional baseball game); Twentieth Century Sporting Club, Inc. v. Transradio Press Serv., Inc., 165 Misc. 71, 300 N.Y.S. 159 (Sup. Ct. 1937) (broadcaster has no right to use broadcast of another as basis for its broadcast of fight).

16. 433 U.S. at 572 \& n.9; see cases cited in note 15 supra. Two other cases the Court cites, Myers v. U.S. Camera Publishing Corp., 9 Misc. 2d 765, 167 N.Y.S.2d 771 (Sup. Ct. 1957); Hogan v. A.S. Barnes \& Co., 114 U.S.P.Q. 314 (Pa. Ct. C. P. 1957), are not in fact right of performance cases, but right of publicity cases, as this Note defines them. See note 7 supra.

Misappropriation derives from the law of unfair competition, which traditionally required proof of the "passing off" of one party's goods as those of a competitor. In INS an action was found to lie even though there was no "passing off." In that case, one news service had used the releases of another to write its own stories. The harm the Court perceived was not that the news service was "passing off" its news stories as those of another, but rather that the news service was profiting at little cost from the work of the other news service. The work the other news service invested in its releases entitled it to a "quasi-property" interest in them. Analogously, Scripps-Howard, instead of itself assembling all that was needed to produce a film of a human cannonball act, took advantage of the work that Zacchini had done.

17. The Court adverts to the unjust enrichment rationale, see 433 U.S. at 576 , before examining Zacchini's performance rights as a copyright analogue.

One difficulty with an unjust enrichment theory, recognized by Justice Powell, see id. at $580 \mathrm{n} .2$ (Powell, J., dissenting), is that the proper measure of damages in an unjust enrichment case is the value of the thing appropriated to the party appropriating it, not the injury the property owner suffers as a result of the loss. The Court, however, did not appear aware that the value of the broadcast to Scripps-Howard could be significantly less than the amount at which Zacchini would part with it in an open market in which he had the power to sell it. See notes 41-47 infra and accompanying text. 
performer's ability to secure legal recognition of his or her power to prevent unauthorized use. ${ }^{18}$ Therefore, as in many areas in which someone asserts a new form of property interest, Zacchini's claim that his right deserves protection because it has market value may be circular: Only if legally protected will the act command a price in the market. If outsiders have ready access to the act, and if no legal action could compel Scripps-Howard to pay Zacchini, neither Scripps-Howard nor anyone else acting in economic self-interest would pay Zacchini anything. The unjust enrichment approach therefore begs the question of why the courts should grant legal recognition to Zacchini's assertion of ownership in his act.

Second, Zacchini could have excluded the press from the performance. Scripps-Howard filmed nothing more than that which Zacchini voluntarily made available to it. Courts of equity traditionally do not order compensation for parties who voluntarily bestow unsolicited benefits on others. ${ }^{19}$ The burden may have been on Zacchini to keep the press from filming him by denying the press access in the first place, ${ }^{20}$ or by conditioning access on the press' agreement not to record or publish any of the act. ${ }^{21}$

18. See Treece, supra note 7 , at $643 \& \mathrm{n} .28$. One must buy bread in the market not merely because one is willing to part with money to enjoy the benefits of eating bread, but also because the owner of the bread can swear out a complaint for theft or sue for conversion if someone takes the bread without paying for it. In many other situations, one can enjoy a benefit at no cost because no action lies for the failure to compensate. For example, a person might be willing to pay a neighbor for the right to enjoy the view of the neighbor's scenic garden, but the viewer will enjoy the benefit without paying because, absent a private bargain, the law does not entitle the owner of the garden to bring an action against viewers. See generally Calabresi \& Melamed, Property Rules, Liability Rules, and Inalienability: One View of the Cathedral, 85 HARv. L. REv. 1089 (1972); Demsetz, Wealth Distribution and the Ownership of Rights, 1 J. LEGAL STUD. 223 (1972).

19. See Dawson, The Self-Serving Intermeddler, 87 HARv. L. REv. 1409 (1974).

20. The press has no right to trespass upon private land to obtain information for a news report, Dietemann v. Time, Inc., 449 F.2d 245, 248-50 (9th Cir. 1971); Le Mistral, Inc. v. CBS, 46 U.S.L.W. 2460 (N.Y. App. Div. Mar. 2, 1978) (television network liable for entering restaurant unannounced with camera rolling), except in cases of such calamities as fires or crimes, Florida Publishing Co. v. Fletcher, 340 So. 2d 914 (Fla. 1976), cert. denied, 431 U.S. 930 (1977).

21. Owners of intangible property may sue parties whom they voluntarily invite to observe the property when the observers expressly agree not to record or exploit what they observe. See Board of Trade v. Christie Grain \& Stock Co., 198 U.S. 236, 250-51 (1905) (Holmes, J.) ("The plaintiff does not lose its rights [to market quotations] by communicating the result to persons, even if many, in confidential relations to itself, under a contract not to make it public, and strangers to the trust will be restrained from getting at the knowledge by inducing a breach of trust, and using knowledge obtained by such a breach."); Dior v. Milton, 9 Misc. 2d 425, 155 N.Y.S.2d 443 (Sup. Ct.), affd mem., 2 App. Div. 2d 878, 156 N.Y.S.2d 996 (1956) (fashion designer may sue for appropriation of design ideas by those admitted to private showing on express agreement not to copy designs). The record in 
The Court in Zacchini properly chose not to dwell on the unjust enrichment approach to Zacchini's claim, shifting its perspective rather to the analogy between rights of performance and copyright law.

\section{B. Zacchini's Claim as a Copyright Analogue}

The purpose of the copyright is, in the words of the Constitution, "to promote . . . Science and useful Arts."22 Unlike a cause of action based on equitable notions of unjust enrichment, copyright protection exists primarily not to benefit the artist, but rather to benefit the public by offering artists economic incentives to create. ${ }^{23} \mathrm{~A}$ copyright is a grant of a limited monopoly power. In a society which values the free exchange of ideas, a grant of copyright necessarily limits the flow of ideas by limiting the means by which these ideas can be expressed..$^{24}$ Copyright law represents a compromise between encouraging the production of new artistic expression and giving the public access to this expression.

The Court did not specifically analyze Zacchini's claim under the federal copyright law, nor does such an analysis by itself firmly resolve the validity of the claim. But the copyright analysis is a useful starting place for considering Zacchini's claim. The question whether Congress has preempted state creation of the right of performance-by either granting Zacchini direct federal protection or denying him protection by intentionally excluding his claim from the scope of copyright-helps focus on the essential nature of Zacchini's interest.

Zacchini does not reveal the extent to which Zacchini tried to prevent the broadcast. Though he told the cameraman not to film him when the cameraman first appeared with his camera, Zacchini did not assert that he tried to stop the cameraman when he returned on the following day to actually film the act. See Appendix at 4, 8-10. Further, because Zacchini charged no separate admission to the area in which he performed, the only relevant restrictions on the cameraman might be those imposed by the people who admitted him to the fair, and no evidence suggests that there were any such restrictions. In fact, the record suggests that those admitting the cameraman welcomed his efforts to film events at the fair: The cameraman was charged no admission fee at all. See Appendix at 10.

22. U.S. ConsT. art. I, $\S 8, \mathrm{cl} .8$.

23. See Mazer v. Stein, 347 U.S. 201, 219 (1954), quoted in Zacchini v. Scripps-Howard Broadcasting Co., 433 U.S. 562, 576 (1977) ("The economic policy behind the clause empowering Congress to grant patents and copyrights is the conviction that encouragement of individual effort by personal gain is the best way to advance public welfare through the talents of authors and inventors in 'Science and useful Arts.' ").

24. Commentators have identified the inherent conflict between the copyright clause and the first amendment. See, e.g., Goldstein, Copyright and the First Amendment, 70 Colum. L. REv. 983 (1970); Nimmer, Does Copyright Abridge the First Amendment Guarantees of Free Speech and Press.? 17 U.C.L.A. L. Rev. 1180 (1970). 
Federal copyright protects only works " 'fixed' in a tangible medium of expression." ${ }^{\prime 25}$ Because Zacchini did not fix his act in such a medium - as he might have done simply by filming it himself ${ }^{26}$ - he has no direct federal cause of action. But the ease with which he could have secured federal protection may argue against giving him any state protection.

Because the copyright act represents a careful balancing of competing interests, ${ }^{27}$ Congress might have intended in enacting the old and new copyright acts to limit the freedom of the individual states to disrupt this balance. The new copyright act in particular abolishes common law copyright ${ }^{28}$ and may, by its language, abolish such other state causes of action as those for invasion of privacy and misappropriation when the subject matter at issue is fixed in a tangible medium of expression. ${ }^{29}$ Congress' decision not to extend copyright protection to Zacchini's act, given its power to do so, may represent a federal policy in favor of public access over economic incentive.

Nevertheless, the legislative history of the new copyright act offers no evidence that Congress carefully considered such a balance. ${ }^{30}$ Further, recent Supreme Court decisions such as Goldstein v. California, ${ }^{31}$

25. 17 U.S.C. app. $\$ 101$ (1976) (definition of "fixed"). For an analysis of the fixation requirement before the new act, see $1 \mathrm{M}$. NIMMER, NIMMER ON COPYRIGHT $\S 8.32$ (1976).

26. A copyright for a film grants the copyright owner not only the right to prevent others from copying the film itself, but also the right to prevent others from making a film that is nearly identical to it. See Gross v. Seligman, 212 F. 930 (2d Cir. 1914) (infringement to sell photograph closely resembling another photograph of the same model). Of course, copyright presumes copying. It therefore may seem anomalous that someone who would never see the authorized film could be held to have breached the copyright that the film secured. Before the new act at least one commentator thought that one who registered a film of an event could secure copyright protection only for the manner in which the event was filmed, not for the event itself. See 1 M. NIMMER, supra note $25, \S 8.32$, at 21 (1976). Under the language of the new act, however, it is clear that the copyright can be secured for an intangible work, such as a pantomime or a dance, see 17 U.S.C. app. $\S 102$ (a) (1976), if the creator fixes the work in a tangible medium of expression. See id. $\S 101$ (definition of "fixed"). A dance can be fixed in a system of notation or in film. In either event, the protection for the dance, as well as the protection for Zacchini's act, is not dependent upon copying from the fixation of the protected work but rather upon copying the protected (albeit intangible) work itself.

27. See Nimmer, supra note 24 , at 1192-93.

28. See 17 U.S.C. app. § 301 (1976).

29. See Goldstein, Preempled State Doctrines, Involuntary Transfers and Compulsory Licenses: Testing the Limits of Copyright, 24 U.C.L.A. L. REv. 1107, 1110-23 (1977).

30. Uncertainty about the role of state law is shown in committee reports and in the floor debate on $\S 301$ of the new copyright act. Id. at 1117 (comparing H.R. REP. No. 2237, 89th Cong., 2d Sess. 129 (1966) ( $\$ 301$ completely preempts state misappropriation doctrine), with H.R. REP. No. 1476, 94th Cong., 2d Sess. 132 (1976) (\$ 301 preempts misappropriation only if based on right within general scope of copyright)).

31. 412 U.S. 546 (1973). 
which recognized California's right to enact a record piracy statute, have interpreted congressional legislation over intellectual properties as leaving states free to create such properties. ${ }^{32}$

Federal copyright law therefore cannot by itself determine the validity of Zacchini's claim. But as a paradigm for balancing incentive and access, it helps identify the factors necessary to such a determination. The copyright analogy, moreover, reveals the specific role the Supreme Court must play in the definition of rights of performance.

\section{The Court's Role in the Press-Performer Conflict}

The first amendment guarantees a public airing of all sides of matters of public interest, whether intellectual, political or aesthetic. ${ }^{33}$ Theoretically, the federal copyright law could unconstitutionally hamper fulfillment of that goal by so limiting the power of the press to appropriate portions of a work as to immunize the work from public scrutiny. But the Supreme Court never has had to address this danger: The potential conflict between copyright and the public interest in uninhibited debate has been resolved through the patient evolution of the fair use doctrine, ${ }^{34}$ which, using equitable

32. The Zacchini Court cited Goldstein as well as its decision in Kewanee Oil Co. v. Bicron Corp., 416 U.S. 470 (1974), which recognized the power of states to act to protect intellectual property as long as they did not interfere with laws passed by Congress, id. at 479 . 433 U.S. at 577-78 n.13. Prior Court holdings in Sears, Roebuck \& Co. v. Stiffel Co., 376 U.S. 225 (1964), and Compco Corp. v. Day-Brite Lighting, Inc., 376 U.S. 234 (1964), had cast doubt on the states' ability to act in these fields. See Goldstein, Kewanee Oil Co. v. Bicron Corp.: Notes on a Closing Circle, 1974 SuP. CT. REv. 81.

33. The Court has recognized "the right of the public to receive suitable access to social, political, esthetic, moral and other ideas and experiences," Red Lion Broadcasting Co. v. FCC, 395 U.S. 367, 390 (1969) (dictum). See Thornhill v. Alabama, 310 U.S. 88, 102 (1940), quoted in Time, Inc. v. Hill, 385 U.S. 374, 388 (1966) ("Freedom of discussion . . . must embrace all issues about which information is needed . . . to enable the members of society to cope with the exigencies of their period."). Alexander Meiklejohn was a principal force in advancing this view of the first amendment. Invoking the metaphor of the New England town meeting, he argued that the first amendment ensured not that everyone be given a chance to speak, but rather that everything worth hearing be said. See A. MEIKLEJOHN, POLITICAL FREEDOM 26-28 (1960).

34. See Cohen, Fair Use in the Law of Copyright, 6 ASCAP COPYRIGHT L. SYMP. 43 (1955). Fair use is incorporated into the new copyright act in $\S 107$ : "[T] copyrighted work, including such use by reproduction in copies or phonorecords or by any other means specified by that section, for purposes such as criticism, comment, news reporting, teaching (including multiple copies for classroom use), scholarship, or research, is not an infringement of copyright. In determining whether the use made of a work in any particular case is a fair use the factors to be considered shall include-

"(1) the purpose and character of the use, including whether such use is of a commercial nature or is for nonprofit educational purposes;

"(2) the nature of the copyrighted work;

"(3) the amount and substantiality of the portion used in relation to the copyrighted work as a whole; and 
rather than constitutional principles, has secured for the press the power to encroach on the ownership of copyrighted works enough to ensure the full scrutiny of those works in the public forum. ${ }^{35}$

Had the Ohio court accurately perceived Zacchini's interest in his act as an intellectual property, it might have properly conceived its role as that of allocating rights to Zacchini's act as a way of guaranteeing the best possible flow of information to the public. ${ }^{36}$ The court might thereby have discovered a rule of "fair use" of performances in its common law and measured the press' interest in broadcasting according to the scope necessary to promote that flow of information. But the Ohio court misperceived Zacchini's interest as a "right of publicity" rooted in the law of privacy, ${ }^{37}$ and therefore, drawing on federal constitutional law, measured Scripps-Howard's interest according to its first amendment right to broadcast newsworthy events. 38

When, as in Zacchint, a state court misperceives the first amendment interest in robust debate in its balance of press and performer interests, the Supreme Court must take greater initiative in identifying that interest itself. Part III of this Note suggests that the Court could have done so by drawing on the copyright fair use model, but first Part II examines the majority and dissenting opinions in Zacchini

"(4) the effect of the use upon the potential market for or value of the copyrighted work."

The power of the press to disseminate its own ideas is also thought to be protected in copyright through the idea-expression doctrine, which holds that copyright does not extend its protection to ideas, but only to original expressions of them. See Nimmer, supra note 24, at 1189-93. This doctrine, however, has limited usefulness in the particular medium of expression in Zacchini-news film-because the means of expressing the idea may be so effective that power to control use of a particular means of expression can be tantamount to controlling expression of an idea. See id. at 1196-200 (using pictures of My Lai massacre as an example).

35. For an example of a case in which, had there been no fair use doctrine, first amendment interests would demand serious attention, see Time, Inc. v. Bernard Geis Assocs., 293 F. Supp. 130 (S.D.N.Y. 1968) (copyrighted Zapruder film of President Kennedy's assassination could be copied because it was an effective means of conveying to the public an assassination theory and such theories were of compelling public interest).

36. The power of the states, as acknowledged by the Court, to create intellectual properties implies the power to allocate rights between press and performer so as to promote the flow of information to the public. Save for the constraint imposed by the first amendment, states are free to decide what allocation gives the public the best possible mix of quantity, quality and variety of information.

For a discussion of the balance between incentive and access as it relates to the respective roles of federal and state authority, see Goldstein, The Competitive Mandate: From Sears to Lear, 59 CALIF. L. REV. 873 (1971).

37. See 433 U.S. at $570-74$.

38. See notes 4 \& 7 supra. 
to evaluate the Justices' success in identifying the factors necessary to resolving first amendment-right of performance conflicts.

\section{The Zacchini OpINIONS: A FaILURe to MONITOR}

As Part I has argued, the Court's essential role in assessing state creation of rights to intellectual property lies in ensuring that works and performances remain available to commentary and criticism in the public arena. The Zacchini majority, making two highly questionable empirical assumptions about the effect of state rights of performance on public debate, concluded that denying a federal constitutional privilege for the press to broadcast a performer's entire act would not inhibit the press to a significant degree, and thus never reached the question of balancing the competing interests. Justice Powell's dissent expressed much greater concern that rights of performance would choke the flow of information to the public, but his standard of constitutional protection for broadcasts used for "routine-news" rather than commercial purposes nevertheless is inadequate to isolate the essential first amendment interest in unconstrained debate.

\section{A. The Majority Analysis}

The axial question in Zacchini is whether public broadcast of Zacchini's act is essential to the first amendment interest in public scrutiny of the act. In concluding that the first amendment did not privilege Scripps-Howard's use of the entire act, the majority made two questionable assumptions. First, it assumed that even if broadcast were essential to public debate, Zacchini's willingness and ability to privately bargain for a licensed broadcast of his act obviated the need for a constitutional guarantee of broadcast. ${ }^{39}$ Second, it assumed that since the press had alternate modes of commentary, broadcast was, in any event, not essential to public scrutiny. ${ }^{40}$ The

39. The Court asserted that an "entertainer such as petitioner usually has no objection to the widespread publication of his act as long as he gets the commercial benefit of such publication," 433 U.S. at 573, and later, appearing to assume Zacchini and Scripps-Howard would have been able to bargain for the right to broadcast if the right were established, the Court stated that "neither the public nor respondent will be deprived of the benefit of petitioner's performance as long as his commercial stake in his act is appropriately recognized," id. at 578.

40. "It is evident, and there is no claim here to the contrary, that petitioner's state law right of publicity would not serve to prevent respondent from reporting the newsworthy facts about petitioner's act." Id. at 574. Earlier the Court distinguished between simply showing the act-which it asserts Scripps-Howard did-and describing or commenting on it. Id. at 569 . 
Court's resulting decision not to privilege the broadcast of an entire act could injure the first amendment interest in criticism of public performances.

\section{The likelihood of a private bargain for broadcast rights.}

Justice White explicitly assumed that judicial recognition of Zacchini's "commercial stake" in his performance would not reduce public access to that performance. ${ }^{41}$ Interpreting Zacchini's request for damages as evidence that he did not object to widespread dissemination of the act so long as he was compensated, ${ }^{42}$ the Court assumed that Zacchini could strike a mutually beneficial bargain with a broadcaster to license a public airing of the act: Though television broadcast might reduce his live gate, Zacchini would be able to obtain from a broadcaster who wanted to show the act more than enough money to make up for the lost revenue; Zacchini would always find that the broadcaster anticipated enough revenue from televising the cannonball act to pay Zacchini enough to ensure that he, Zacchini, profited from the transaction as well.

The majority thus did not even have to reach the question of whether the constraint that the grant of a right of performance might impose on dissemination of the act would harm the first amendment interest in robust debate, since the majority was assuming that the right of performance would not constrain dissemination in the first place. But the empirical basis of this assumption may be very fragile. The majority insufficiently examined the costs and benefits of Zacchini's alternative means of disseminating his act, and did not realize that other performers might have different costs and benefits. Further, the court did not recognize-as Zacchini and other performers might-that the widest possible dissemination does not ensure the greatest profits.

Zacchini would expend the same amount of talent and energy performing before a television audience of millions as before a county fair audience of one hundred. The broadcast imposes no extra performance costs on him. ${ }^{43}$ Assuming that the broadcast does not affect

41. Id. at 578.

42. See id. at 573-74.

43. In economic terms, the broadcast of the act is a "public good" because the cost of production bears no relation to the number of consumers. See B. OWEN, J. BeEbE \& W. Manning, Television Economics 15-16 (1974); Demsetz, The Private Production of Public Goods, 13 J.L. \& ECON. 293 (1970).

Of course, when performers license a broadcast, they may alter their performances to appeal to a wider audience or adjust to the broadcast medium. For example, in his first 
the size of his live gate, Zacchini will profit by licensing the right to broadcast his act. Not to do so would be to reject additional revenue that entails no additional cost. If by enhancing his renown the broadcast actually increases his live gate, ${ }^{44}$ Zacchini might allow the broadcast even without exacting a licensing fee, since once again a broadcast would increase revenue without creating expense.

Television broadcast of his entire performance, however, if it faithfully reproduces the sensory and emotional effects of attendance at the fair, may reduce the size of Zacchini's live gate. ${ }^{45}$ By permitting the broadcaster to televise the act, Zacchini may sacrifice substantial live gate revenue for a small licensing fee. If the price the broadcaster offers, as determined by its estimate of the profits from broadcast, ${ }^{46}$ does not exceed Zacchini's anticipated loss in live gate revenue, no bargain will occur. The economically rational performer will aim at the greatest possible profit, whether by licensing a full network broadcast, a limited-audience closed-circuit broadcast, or no broadcast at all. ${ }^{47}$ Some rationally self-interested performers

boxing match with Joe Frazier, Muhammad Ali wore red trunks rather than his usual white with black trim because of the color telecast. Wallace, Worldwide Televising of Fight is Biggest Item in a \$25-Million Gamble, N.Y. Times, Mar. 7, 1971, § 5, at 2, col. 1. But performers do not need to alter their acts for broadcast. Zacchini might theoretically have done so, but since he was unwilling to be filmed, he was not likely to oblige the cameraman by altering the act in any way, and in any event the record fails even to indicate if he knew he was being filmed at the actual time of his performance. See Appendix at 8-10, Zacchini v. ScrippsHoward Broadcasting Co., 433 U.S. 562 (1977).

44. The Court conceded this possibility, 433 U.S. at $575 \mathrm{n} .12$ ("It is possible, of course, that respondent's news broadcast increased the value of petitioner's performance by stimulating the public's interest in seeing the act live."), and Scripps-Howard's commentary on the Zacchini film expressly encouraged viewers to see the act, see note 51 infra. Because the Court was only reviewing a summary judgment, for the purpose of analyzing the sufficiency of the complaint it assumed that the broadcast did injure Zacchini. But the Court's uncertainty about the extent of the damages undercuts its conclusion that the economic value of the act was so seriously undermined by the broadcast as to rebut any claim of a press privilege.

45. For example, studies conducted following the passage of a federal law mandating local broadcasts of some professional athletic contests, Act of Sept. 14, 1973, Pub. L. No. 93-107, 87 Stat. 350, showed that even some who bought tickets to games would stay at home to watch the games on television. No Blackout Brings Drop at 9 Games, N.Y. Times, Sept. 17, 1973, at 43, col. 8. The act expired by its own terms 2 years later in 1975. Professional football teams have continued to follow it, perhaps because if they did not, Congress might pass a similar law that was more burdensome.

46. Television derives its profits from commercial advertising revenue. The amount of revenue a television station commands from advertisers depends on the size and the characteristics-age, sex and income-of the audience its programming is expected to attract. B. OWEN, J. BEEBE \& W. MANNING, supra note 43, at 4-6.

47. In Portland, Oregon, a downtown movie theater shows home basketball games on closed-circuit television. Kirkpatrick, A fever called Blazemania, SPORTS IlluSTRATED, Oct. 31,1977 , at 36-37. A local television station in Portland shows away games and probably 
could find it unprofitable to license widespread broadcast of their acts. Others would find it profitable to do so. Even on the bare record it received from the Ohio courts, the majority may have correctly inferred that Zacchini fell into the second category. But because it did not address the complexities of cost and benefit, it did not perceive the difficulty of determining into which category future performers would fall.

\section{The limitation on the press' ability to comment.}

In insisting that Zacchini would not object to widespread dissemination of his act so long as he was compensated, Justice White concluded that rights of performance do not affect whether an act is disseminated, but only who would do the disseminating. ${ }^{48}$ His opinion thereby implied that the mere dissemination of the act protected first amendment interests, and thus did not isolate the first amendment interest at stake in the creation of rights of performance-the airing of the performance in a critical forum.

Even if Zacchini's economic self-interest ensured the dissemination of his act, it would not ensure dissemination of all relevant information about the act. Zacchini wants praise, not criticism. ${ }^{49}$ His interest in broadcasting the act lies in the capacity of film and television to enhance his reputation and the market value of the act, as well as in the licensing fee he might receive. Scripps-Howard's interest, on the other hand, may well be to convince the public that it is an acute and reliable guide in selecting and judging public entertainments. The majority's neglect of the different interests the two poten-

would be willing to pay to broadcast home games as well. Presumably, it fails to secure the right to broadcast the home games because it cannot compete with the closed-circuit operators, who not only can pay a sizable licensing fee, but who can also claim to disturb live-gate revenues less. Economically rational owners would choose limited-access secondary transmission only if it maximized total revenue. Zacchini might likewise refuse to license local broadcasting of his act, if performing exclusively before live audiences maximizes his profits. For a discussion of the different approaches to dissemination of sporting events, see Koppett, Should the Federal Government Encourage Presentation of Sports on Pay Television?, N.Y. Times, Nov. 9, 1976, at 43, col. 1 (asserting local-interest or routine sports programming likely to stagnate or decrease without pay television). For a critical look at restricted broadcasts, see Gould, The Fight: TV Fan Counted Out, N.Y. Times, March 8, 1971, at 67, col. 2 (critical reaction to longterm "threat" posed by prospect of telecasts with restricted access after first Ali-Frazier fight).

48. 433 U.S. at 573.

49. Even negative criticism can give performers exposure that results in greater profits, but such is not the usual case, especially if the criticism is both extremely negative and extremely persuasive. Revenues typically will decline if the act is effectively criticized and this decline in revenue typically will exceed the amount of revenue gained by licensing the dissemination of the critical commentary. The economically rational performer would have no incentive to allow criticism that led to a decline in revenue. 
tial disseminators might have in the broadcast led it away from appreciating the true first amendment interest at stake.

Moreover, Justice White insisted that the state right of performance would not prevent the press "from reporting the newsworthy facts" about the cannonball act. ${ }^{50}$ If the majority offered this assertion as evidence that the state right of performance would not injure the first amendment interest in the public scrutiny of performances, it must have assumed that a constraint on the power to broadcast the act would not entail a constraint on the power to criticize the act.

The facts of Zacchini might suggest that the question of "criticism" does not arise in the case at all. Scripps-Howard's lighthearted and unmitigated praise of the act ${ }^{51}$ does not seem to be critical commentary. Yet merely by deciding what to broadcast and what to leave on the cutting room floor, Scripps-Howard shapes public opinion. Moreover, however positive in tone and content, ScrippsHoward's presentation of the act consisted generically of qualitative judgments; its assertion that the act was a "thriller" rather than a waste of time constitutes and invokes public debate on a matter of aesthetic criticism.

The majority's assumption does not isolate this interest in criticism underlying the purportedly protected interest in "reporting." And this assumption, like the first, has an unstable foundation. Film conveys information about an act that spoken words cannot. ${ }^{52}$ If spoken words or even still pictures were a perfect substitute for film, Scripps-Howard would not pay a cameraman to film Zacchini. ${ }^{53}$ The

50. 433 U.S. at 574.

51. The complete text of the commentary accompanying the film is reprinted in id. at $564 \mathrm{n.1}$ ("This . . now . . . is the story of a true spectator sport . . . the sport of human cannonballing . . . in fact, the great Zacchini is about the only human cannonball around, these days . . . just happens that, where he is, is the Great Geauga County Fair, in Burton ... and believe me, although it's not a long act, it's a thriller . . . and you need to see it in person . . . to appreciate it . . ." (emphasis and ellipses in original; ellipses indicate pause)).

52. The Court confronted a claim involving the relative effectiveness of different media in conveying information in Nixon v. Warner Communications, Inc., 98 S. Ct. 1306 (1978). The press plaintiff sued for access to tape recordings of former President Nixon's conversations with his staff, recordings which had been introduced as evidence in a criminal trial. Although the common law right of access to judicial documents allowed Warner to reproduce the words on the tapes from written transcripts, Warner claimed a first amendment right to make aural reproductions of the tapes for commercial distribution. Id. at 1317. In addition to asserting a privacy right to block Warner's claim, Nixon argued that he had a proprietary interest in the representation of his voice on the tapes, as opposed to an interest in the tapes themselves. Id. at 1313. The Court, however, did not have to balance the competing interests in the case, since Congress had established a special administrative procedure for controlling dissemination of the tapes. Id. at 1315.

53. Television news has recently increased its reliance on film, presumably because the ability of film to attract audiences outweighs its expense. See McDaniel, Film's Presumed Ad- 
most effective way to convince the public that the cannonball act was exciting or thought-provoking on the one hand, or dull or offensive on the other, might be to juxtapose a film clip to spoken commentary.

The first amendment may not demand that the press have the best possible means of expressing its ideas. ${ }^{54}$ But by assuming that the power to broadcast was not essential to the power to report-and, by inference, to the power to evaluate-the majority only superficially monitored the state's creation of the right of performance to protect robust debate from constriction.

\section{The "entire-act" standard.}

The Zacchini majority first assumed that Zacchini's economic selfinterest would lead him to license a broadcast of the act, and then assumed that in any event Scripps-Howard did not need the broadcast to perform its constitutionally sanctioned role as critical commentator. The majority went on to declare that the first amendment did not privilege press appropriation of a performer's entire act. ${ }^{55}$ But because of its assumptions, the majority, in formu-

vantages in Presenting Television News, 50 Journalism Q. 146 (1973). Of course, Scripps-Howard's preference for film is not itself dispositive of its right to use it in this case. Its need may be small, and its preference may be based on a desire to exploit Zacchini for its own profit, rather than to improve its critical commentary. But since in merely mentioning the act Scripps-Howard may contribute to public debate by focusing public attention on a particular cuItural experience, any state law limitation on the press' ability to convey information about a performance risks offending the first amendment. For a discussion of the difficulty of categorically distinguishing "news" from "commercial" purposes of infringement, see notes 60-67 infra and accompanying text.

54. Such a press privilege would be so broad as to interfere with other interests. The limits on ways in which states may control the time, place and manner of speech in public forums provide a useful analogy. See, e.g., Cox v. New Hampshire, 312 U.S. 569 (1941) (parade permit ordinance constitutional). Time, place and manner regulation, however, is subject to close examination and frequently falls to first amendment interests. See, e.g., Linmark Assocs., Inc. v. Township of Willingboro, 431 U.S. 85, 93 (1977) (ban on "for sale" signs unreasonable restriction on free speech because alternatives-newspaper ads and real estate listings-too burdensome); Virginia State Bd. of Pharmacy v. Virginia Citizens Consumer Council, Inc., 425 U.S. 748, 771 (1976) (statute forbidding advertising of pharmaceuticals plainly exceeded proper time, place and manner restrictions on commercial speech); Saia v. New York, 334 U.S. 558, 561 (1948) (local ordinance permitting sheriff to prohibit use of loudspeakers violates first amendment as loudspeakers are "indispensible instruments of effective public speech").

55. "Wherever the line in particular situations is to be drawn between media reports that are protected and those that are not, we are quite sure that the First and Fourteenth Amendments do not immunize the media when they broadcast a performer's entire act without his consent." 433 U.S at 574-75.

Copyright cases offer some support for the proposition that no right to appropriate an entire work exists. Cf. Benny v. Loew's, Inc., 239 F.2d 532, 536-37 (9th Cir. 1956) (Benny's 
lating its standard, did not have to confront the potential "hard case" in which a performer would find it economically disastrous to license a broadcast which a broadcaster clearly needed in order to comment on a performance. The striking facts of Zacchini may have justified the inference in this particular case that broadcasting the entire act was tantamount to "preventing [Zacchini] from charging an admission fee"56 and that the broadcaster could have carried out its critical role by noninfringing means. ${ }^{57}$ But the bare record the majority faced on both these questions may have prevented the Court from examining them in sufficient detail to justify a general entire-act rule. The rule may be sufficiently narrow that it does not create unfortunate precedent. But the entire-act standard only imprecisely addresses the general question of the relative interests of press and performer, and, by leaving the ultimate protection of the press to the potentially chilling decisions of state courts when "entire acts" are appropriated, the standard invites injury to first amendment principles.

In ordinary cases, the entire-act standard will probably run no risk of curtailing first amendment interests. For example, further litigation consistent with Zacchini might establish that owners of baseball teams have a right of performance to control the dissemination of films of entire games, but not the right to prevent or license broadcast of highlights of the games. A property interest in broadcast of the whole game may gain the owners additional revenue if the games are of sufficient interest to attract licensees; the prospect of

satire of plaintiff's film Gaslight deemed a taking of the whole). But of. Berlin v. E.C. Publications, Inc., 329 F.2d 541, 544-45 (2d Cir. 1964) (satiric paraphrasing of song lyrics held fair use). Yet it is unlikely that this concept of the taking of an "entire work" would apply to a critic's use of an entire poem, if the poem were short. For example, consider Ezra Pound's poem "In a Station of the Metro":

The apparition of these faces in the crowd;

Petals on a wet, black bough.

A critic's use of the poem would likely be considered fair use, even though the critic makes use of the entire poem. A fair use claim, however, might not exist if infringers disseminated Pound's poem without any criticism at all, as they might if they used it on a greeting card. For a discussion of this issue, see $2 \mathrm{M}$. NIMMER, supra note $25, \S 145$, at 651 ("It would seem, nevertheless, that there may be certain very limited situations wherein copying of even the entire work for a different functional purpose may be regarded as fair use.").

56. See 433 U.S. at 576.

57. Zacchini was not, to pick several examples, like night club improvisationists, whose performances undergo continuous change, or like folk singers, who have large repertoires and who can attract considerable followings that see them perform multiple times. Zacchini's act was the same as his father's and appears to have remained essentially unchanged for 50 years. See Appendix at 4. Further, a cannonball act is a stunt that attracts audiences because it appears dangerous. Very likely, it becomes less interesting after repeated exposure. 
additional revenue might be an incentive for owners to attract superior players who play more exciting games, and so the long-range public interest in better performances might favor a right of performance in this case. Whatever revenue the owners lose from not being able to license broadcast highlights might be very small, however, and conceivably outweighed by the press need to comment on the games by using the highlights.

Nevertheless, the entire-act standard invites neglect of the factors involved in accommodating economic incentive and first amendment access, a neglect that might manifest itself in "hard cases." The majority presumed that the essence of a performance-that core experience that the public will pay to enjoy-would be appropriated by broadcast of an entire act. ${ }^{58}$ But even though a film may record the entire duration of an act, the difference in sensory and emotional experience between live attendance and the imperfectly faithful medium of television film may mean in a significant number of cases that filming the entire act would not appropriate the essence of the act at all and therefore would not pose a substantial economic threat to the performer.

The majority also presumes that the press would never need to film the entire act to effectively criticize it. But cases may arise to destroy this presumption. For example, a broadcaster might endeavor to expose Zacchini as a charlatan who uses wires and mirrors to perform his act. The public's interest in scrutiny of the act might only be served by a film covering every aspect of the act from the preparation of the cannon through Zacchini's landing.

Finally, the concept of an entire act may suffer a fundamental ambiguity: defining the scope of an act. A performer might try to rebut a claim of privilege by asserting that a discrete unit that is part of a larger whole is, in fact, an entire act. ${ }^{59}$ In such a case, a court, attempting to construe the Zacchini standard might end up focusing

58. See 433 U.S. at 575-76. But see id. at $575 \mathrm{n} .12$ (conceding broadcast could stimulate interest in the act).

59. Justice Powell argues that the issue is relevant even in Zacchini itself: The newsclip, showing Zacchini's flight through the air, is arguably not a film of the "entire act," because a large part of the "act" may be the fanfare that precedes the actual flight. Id. at $579 \mathrm{n} .1$ (Powell, J., dissenting). Justice Powell adds that the question is "especially likely to arise when the editor receives film footage of an event at a local fair, a circus, a sports competition of limited duration (e.g. the winning effort in a ski-jump competition), or a dramatic production made up of short skits, to offer only a few examples." Id. at 580 n.3 (Powell, J., dissenting).

A further potential ambiguity in the entire act concerns the nature of the medium by which the act is recorded. Scripps-Howard used news film. A videotape of the act might 
on the discrete unit and not on the balance between the competing interests.

Concentrating on the facts before it at the expense of the underlying broader issues, the majority left lower courts with little guidance in resolving the tension between incentive and access. The cloudy boundary between rights of performance and the first amendment may ultimately harm both press and performer by achieving unprincipled results.

\section{B. The Powell Dissent: A "Routine-News" Test}

Perhaps because it did not foresee state rights of performance seriously impinging on the first amendment, the majority drew a very narrow holding, giving the states little guidance in defining the still uncertain boundary between rights of performance and public debate. Justice Powell, apparently sensing that such uncertainty might chill freedom of expression, offered a firm general rule for limiting the reach of rights of performance. The press should be privileged to appropriate any portion or all of a performance so long as it broadcasts the performance as part of its routine news programs rather than as commercial entertainment. ${ }^{60}$

The news-commercial distinction resembles the common law distinction in rights to privacy between commercial and noncommercial use of names and likenesses, ${ }^{61}$ and draws on first amendment law in the privacy and libel areas, in which the Constitution protects from state tort suits publications dealing with public figures or matters of newsworthy interest. ${ }^{62}$ But the great difference between rights of performance cases-in which the question is who does the publish-

have reproduced its sensory effects more or less faithfully than film. The Court's analysis does not address such potential differences in defining an "entire act."

60. "In my view the First Amendment commands a different analytical starting point from the one selected by the Court. Rather than begin with a quantitative analysis of the performer's behavior-is this or is this not his entire act? - we should direct initial attention to the actions of the news media: what use did the station make of the film footage? When a film is used, as here, for a routine portion of a regular news program, I would hold that the First Amendment protects the station from a 'right of publicity' or 'appropriation' suit, absent a strong showing by the plaintiff that the news broadcast was a subterfuge or cover for private or commercial exploitation." 433 U.S. at 581 (Powell, J., dissenting) (footnote omitted); see The Supreme Court, 1976 Term, 91 HaRv. L. Rev. 70, 213-14 (1977) (advocating Justice Powell's test). 1971)

61. See W. Prosser, Handbook of the LaW of TORTs $\S 117$, at 806-07 (4th ed.

62. The scope of first amendment protection in the context of libel law is discussed in Gertz v. Robert Welch, Inc., 418 U.S. 323 (1974), cited in 433 U.S. at 582 (Powell, J., dissenting). See Virgil v. Time, Inc., 527 F.2d 1122 (9th Cir. 1975) (press first amendment privilege in context of right to privacy). 
ing-and privacy and libel cases-in which the question is whether there should be publication at all-makes the Powell test inadequate to comprehend the issues raised in Zacchini ${ }^{63}$

Labeling broadcasts as "news" or "commercial entertainment" is too blunt an instrument for measuring the need for incentive against the need for access. Blanket protection for appropriation of an act for a routine news program may overly constrict the ability of the states to establish rights of performance, and might enable a broadcaster to inflict serious and pointless financial harm on a performer by showing far more of an act than is really necessary to its critical purpose.

Yet the Powell test may be even less sensitive to the proper measure of the press interest. Contemporary television treatment of sports events illustrates the artificiality of and problems that may be wrought by distinguishing "news" from "commercial" broadcasts. Filmed sports highlights appear on local evening news shows and on such presumably "commercial" programs as post-game interview spots with athletes. The Powell standard might protect the former use but not the latter, even though the two uses convey the same essential information to satisfy the same essential audience interest.

The dissent attempted to fine-tune its standard by stressing that the routine-news privilege would not extend to news broadcasts a court deemed "subterfuges" for commercial exploitation. ${ }^{64}$ Such a limit to the routine-news privilege, however, presumes a highly unrealistic distinction between the motivations of news editors and commercial programmers. ${ }^{65}$ Producers of local news programs strive

63. Justice Powell appears to equate events that are "newsworthy" with events that the press has a right to film for use on its regular news programs. 433 U.S. at 581 (Powell, J., dissenting). But this test, designed for privacy and libel cases, is less appropriate when rights of performance are involved. The purpose of the first amendment is at least partially to ensure that the public gains access to information. See A. MEIKLEJOHN, supra note 33, at 26-28. A measure of "newsworthiness" is therefore appropriate in privacy and libel cases because it ensures that the public is informed of newsworthy events by giving the press the right to disseminate information private individuals are unlikely to release. Rights of performance, however, restrict the press' power in order to provide public performers with the economic incentives necessary to create the event that the public desires access to. A newsworthiness test limiting the scope of rights of performance could actually reduce public access to information, because it might cause fewer performances to take place. See generally Hancock, Fallagy of the Transplanted Calegory, 37 CAN. B. REv. 535 (1959).

64. 433 U.S. at 581 \& n.4 (Powell, J., dissenting).

65. The entertainment aspects of local news programming have become increasingly evident with the advent of the "happy talk" news format adopted by numerous local programs. See Dominick, Wurtzel \& Lometti, Television Joumalism v. Show Business: A Content Analysis of Eyewilness News 52 JouRNALISM Q. 213, 218 (1975) ("[I]t appears some news direc- 
constantly to obtain the most attractive stories and film footage in an effort to win the endless advertisement and ratings war with competing stations. ${ }^{66}$ They may be every bit as commercially minded as the variety show producer attempting to line-up the most spectacular array of stars. ${ }^{67}$

Though properly sensitive to the advantage of a clear rule to prevent the self-censorship of the press, the dissent's deceptively precise standard might severely constrict the power of the states to strike the proper balance between performer incentive and press scrutiny of performances.

\section{A "FAIR Use" STANDARD FOR Rights OF PeRformance}

In copyright law, the fair use doctrine mediates between the press' interest in criticism and reporting and authors' and artists' interest in economic incentive. Accommodation of the competing interests of the press and performers requires a tool of mediation analogous to fair use. ${ }^{68}$

Fair use looks to two principal factors in determining the right of a press party to infringe on a particular intellectual work: (1) the purpose of the infringing expression; and (2) the scope of the infringement and the resulting degree of economic injury to the artist. ${ }^{69}$ Another factor at work which, though not codified, has been identified in fair use case law $^{70}$ is the presence or absence of alternate means by which the press can fulfill the purpose of its infringement. The first factor as applied to first amendment-right of performance conflicts

tors may be viewing news shows as a form of entertainment first and information programs second.").

66. See McDaniel, supra note 53; Dominick, Wurtzel \& Lometti, supra note 65. The desire to increase ratings of local news programs is also evidenced by the constant shufling of anchorpersons. See, e.g., Two Anchormen Hired by WABC-TV, N.Y. Times, June 11, 1975, at 87, col. 4.

67. For a discussion of the role that news programs, which appear to fill a public service function, play in the profit-maximizing strategy of television station owners, see B. OWEN, J. BEEBE \& W. MANNING, supra note 43, at 5-6.

68. The analogy to fair use is also suggested, though not developed, in Comment, Privacy, Appropriation, and the First Amendment: A Human Cannonball's Rather Rough Landing, 1977 B.Y.U. L. REV. 579, 606.

69. This summary of fair use reduces the four factors in $\S 107$ of the new copyright act to two. The first factor corresponds to $\S 107(1),(2)$ and the second to $\S 107(3),(4)$. For a different summary of fair use, see Goldstein, supra note 24, at 1012-14.

70. See, e.g., Walt Disney Prod. v. Air Pirates, 345 F. Supp. 108, 115 (N.D. Cal. 1972) (alternative means characterized as first amendment interest, and found to be available); Time, Inc. v. Bernard Geis Assocs., 293 F. Supp. 130, 146 (S.D.N.Y. 1968) (alternative means not available). In much of copyright law, no need exists for such a factor in fair use because of the operation of the idea-expression distinction, but the distinction has limited usefulness in news-film cases, see note 34 supra. 
identifies the broad purpose the press advances-criticism-but is of less use in balancing the competing interests. The other two factors, however, can provide a basis for a "fair use" doctrine for rights of performance.

The fair use doctrine, in addition to protecting limited infringements for educational and research purposes, ${ }^{71}$ protects infringements that the press employs for the purpose of criticism and commentary. The purpose test, however, is not helpful in drawing subtle distinctions among the types of press airings of performances. As this Note's analysis of the Powell dissent in Zacchini has shown, the advent of commercial television has blurred any distinctions that traditional copyright law might once have identified between "serious" journalistic and "commercial" infringements. ${ }^{72}$

The second factor-the damage done to the performer's incentive-is more readily applicable to rights of performance cases. In announcing the "entire-act" standard, the Zacchini majority recognized the importance of measuring the economic disincentive caused by an unlicensed broadcast of a performer's act. But as argued above, that disincentive is inadequately measured by the arithmetic portion of the duration of an act that is appropriated. ${ }^{73} \mathrm{~A}$ "fair use" test for performance rights requires precise determination of economic disincentive. Performers will inevitably lose some revenue if courts deny legal recognition to their power to license broadcasts of their acts. But the vast bulk of a performer's revenue may derive not from the right to control broadcasts, but from the right to prevent people from seeing his live act unless they pay to do so. Since the purpose of a right of performance is to secure economic incentive, courts must determine on solid evidence the actual disincentive broadcasts may cause.

The availability of alternative means of expression was a factor both the Court's and Justice Powell's opinions adverted to obliquely. In asserting that the press could convey newsworthy facts about Zacchini without broadcasting his act, ${ }^{74}$ the Court indirectly adverted to the difficulty it would face if the only effective means of

71. See 17 U.S.C. app. $\S 107$. For an argument that such an application of fair use is inappropriate, at least when transaction costs and the probability of an infringement action are low, see Goldstein, The Privale Consumption of Public Goods: $A$ Comment on Williams \& Wilkins Co. v. United States, 21 Bull. Copyright Soc'y 204 (1974).

72. See notes $60-66$ supra and accompanying text.

73. See notes 55-59 supra and accompanying text.

74. See 433 U.S. at 574; notes $48-54$ supra and accompanying text. 
expression available to the press required infringement of the performer's interest. By asserting that the Court's decision would chill freedom of expression, ${ }^{75}$ Justice Powell's dissent suggests that a different case would emerge if the performer's right did not censor the press. Though they reached opposite conclusions on the facts before them, both the majority and Justice Powell suggest that an important factor in determining the scope of a press privilege is the room a right of performance would leave the press to find effective alternative modes of conveying the same information about the act. A press defendant sued for filming a performance might be asked to demonstrate that filming a smaller portion of a performance or depicting it through still pictures or mere verbal summary would be inadequate to convey legitimate commentary on the performance.

Though the Court in Zacchini confronted a thin record, the striking facts it did have may permit application of these "fair use" criteria. Zacchini's act was his entire livelihood, and a television film of the act from blast-off to landing probably threatened a severe loss of live gate revenue. ${ }^{76}$ Scripps-Howard might well have achieved its modest goal of recommending the act to its viewers as an exciting entertainment by use of a few still pictures and vivid laudatory words. The Court's decision on these facts therefore appears to be correct. But Justice White's formulation of a general rule out of the bizarre facts of Zacchini might discourage the discovery of the more thorough evidence that might be crucial to future right of performance cases. A "fair use" test incorporating the criteria outlined above might have prompted the state courts to develop the records necessary to assure correct decisions in the future. ${ }^{77}$

\section{Conclusion}

The decision of the United States Supreme Court in Zacchini $v$. Scripps-Howard Broadcasting Co. that the press has no federal constitu-

75. See 433 U.S. at 580-81 (Powell, J., dissenting).

76. See note $\mathbf{5 7}$ supra.

77. A possible remedy, less drastic than a press privilege, is to compel performers to license broadcasts of their acts. Cf. Nimmer, supra note 24, at 1196-200 (suggesting compulsory licensing of news photographs). But because private bargaining between performer and broadcaster should not require high transaction costs, compulsory licensing probably would not make possible broadcasts that were unprofitable before because of the costs of negotiating a license. The principal consequence of a compulsory licensing scheme might well be to reduce the performer's bargaining power and thereby the performer's economic incentive, an incentive that the state found necessary to ensure production of performances. Under these conditions, compulsory licensing, like any other remedy, should only come when the first amendment interests are found to outweigh the interest in preserving the accommodation of access and incentive the state has struck. 
tional right to broadcast a performer's entire act involves important first amendment interests. In essence, the opinion holds that the press' first amendment interest in access does not justify filming a performer's entire act if state law grants performers a proprietary interest in their acts. In reaching this conclusion, the Court assumed that performers would not deny broadcast rights if compensated and that the press could report effectively on performers and their acts without using film. The record in Zacchini, however, provided an insufficient basis on which to make these general assumptions. Moreover, the Court's entire-act standard does not focus on the central conflict between incentive and access. The Court did not clearly articulate the role it ought to have played. Although states can determine the allocation of rights between press and performer, the Court must ensure that such allocations do not unduly constrict public debate. Since intellectual property rights can disrupt as well as promote the exchange of ideas in the marketplace, the Court must be prepared to police the balance that the states strike. This Note has argued that the Court can ensure that first amendment interests are accommodated by drawing on copyright fair use doctrine and privileging press commentary and criticism when the economic disincentive the privilege disrupts is outweighed by the inadequacy of the alternative avenues of expression available to the press. Yet this Note has also argued that the first amendment principles the Court establishes should allow states freedom to evolve their own equitable principles of accommodation. To the extent the Zacchini opinion allows such evolution, it does not disserve the competing interests of press and performers. 
HeinOnline -- 30 Stan. L. Rev. 1210 1977-1978 